\title{
TRIGEMINAL SENSORY NEUROPATHY AND FACIAL CONTACT DERMATITIS DUE TO Anthurium sp
}

\author{
Carlos A. Twardowschy', Hélio A.G. Teive1, Fábio Siquineli", Léo Ditzel Filho', \\ Marlene Entres², André Twardowschy', Lineu César Werneck ${ }^{1}$
}

\begin{abstract}
Background: Trigeminal sensory neuropathy (TSN) describes a heterogeneous group of disorders manifesting as facial numbness. Objective: We report the case of a patient who had TSN associated with contact dermatitis due to Anthurium sp. Method/Results: A 21-year-old female patient developed left hemifacial contact dermatitis after exposure to the anthurium plant. The patient had paresthesias and pain in the V2 and V3 divisions of the left trigeminal nerve. Eight days after its onset the dermatitis resolved, but numbness developed in the V2 and V3 divisions of the left trigeminal nerve. Cranial CT scan and MRI, as well as CSF and extensive work-up exams, were normal. After one month the symptoms disappeared completely. Conclusion: Anthurium sp, an indoor ornamental plant that contains calcium oxalate crystals, and can causes contact dermatitis. To our knowledge, this is the first report associating TSN with contact dermatitis due to Anthurium sp.
\end{abstract}

KEY WORDS: trigeminal sensory neuropathy, facial contact dermatitis, Anthurium sp.

\begin{abstract}
Neuropatia trigeminal sensitiva e dermatite de contato facial por Anthurium sp
RESUMO - Introdução: A neuropatia trigeminal sensitiva (NTS) representa um grupo heterogêneo de doenças, cuja manifestação clínica é a presença de dormência na região facial. Objetivo: Relatamos o caso de paciente que apresenta NTS associada com dermatite de contato (DC) devido à planta Anthurium sp. Método/Resultados: Uma paciente com 21 anos desenvolveu DC na região hemi-facial esquerda, após exposição à planta Anthurium sp. Após a resolução do quadro de dermatite, a referida paciente apresentou dormência e parestesias no território do segundo e terceiro ramos do nervo trigêmeo esquerdo. Um mês após o início do quadro houve resolução completa dos sintomas. Conclusão: O Anthurium é uma planta ornamental que contém cristas de oxalato de cálcio, que podem causar DC. Para o nosso conhecimento este é o primeiro relato associando NTS e dermatite de contato devido à exposição ao Anthurium sp.
\end{abstract}

PALAVRAS-CHAVE: neuropatia trigeminal sensitiva, dermatite de contacto facial, Anthurium sp.

Trigeminal sensory neuropathy (TSN) is a rare disease characterized by sensory disturbances (numbness and paresthesias) in one or more divisions of the trigeminal nerve ${ }^{1-4}$. When an apparent cause is not detected, the disease is defined as idiopathic trigeminal sensory neuropathy (ITSN), which is usually transient ${ }^{2,4}$.

ITSN is always considered an exclusion diagnosis, so that various systemic, intracranial and extracranial disorders must first be eliminated. Classically, involvement of the trigeminal nerve is related to demyelinating diseases, the presence of tumors, vascular diseases, trauma, local injections, terminal kidney disease, infections, drugs and connective tissue diseases $^{1-13}$. Of this group of disorders, multiple sclero- sis and connective tissue diseases, as well as ITSN, are of particular importance ${ }^{1,4}$.

The aim of this study is to report the case of a female patient who developed trigeminal sensory neuropathy associated with facial dermatitis following direct contact with an ornamental plant known as anthurium (Anthurium sp.).

\section{CASE}

We report the case of a 21-year-old female patient who was referred to the Neurology Service Outpatient Department at the Hospital de Clínicas, Federal University of Paraná, complaining of paresthesias in the left perioral facial region. The patient reported that eight days before the visit she had suddenly developed edema, rubor, pain and paresthesias in the left perioral region following direct con-

\footnotetext{
${ }^{1}$ Neurology Service, Internal Medicine Department, Hospital de Clínicas, Federal University of Paraná, Curitiba PR, Brazil; ${ }^{2}$ Center for Poisoning Control, Paraná Department of Health, Curitiba PR, Brazil.
}

Received 22 February 2007. Accepted 22 May 2007.

Dr. Hélio A.G. Teive - Rua General Carneiro 1103/102 - 80060-150 Curitiba PR - Brasil. E-mail: hagteive@mps.com.br 
tact with an anthurium plant (Anthurium sp.). The inflammatory symptoms resolved in the following eight days after the use of a topical corticosteroid prescribed by a dermatologist. However, the patient continued to suffer from pain and paresthesia in the left hemifacial maxillary and mandibular regions. Neurological examination, which was carried out eight days later, was normal except for tactile hypoesthesia and paresthesias in the territory of the second and third divisions of the left trigeminal nerve.

Routine laboratory tests, which included hemogram, ESR, urea, creatinine, fasting glycemia, sodium, potassium, calcium, phosphorous, liver-function tests, VDRL, antinuclear antibody test and mucoproteins were normal. Neuroimaging tests, such as computerized tomography (CT) and magnetic resonance imaging (MRI) of the skull, and cerebrospinal fluid (CSF) examination were normal.

The patient was medicated with carbamazepine in increasing doses up to $600 \mathrm{mg}$ a day with good control of the symptoms. The patient's condition improved completely after 30 days and the treatment was stopped.

\section{DISCUSSION}

Trigeminal sensory neuropathy is a challenging diagnosis with an extensive list of possible differential diagnoses (Table). It may often represent the first manifestation of a serious pathology, such as neopla- sia $^{1,3,5}$. Neoplastic trigeminal neuropathy corresponds to a small percentage of trigeminal neuropathies. In most cases, there is already a history of neoplastic disease, and the tumor lesion is usually located in the jaw; prognosis is generally very poor ${ }^{1,5}$.

TSN can also occur secondarily to connective tissue diseases, and various reports of TSN associated with Sjogren's disease have been published. Of particular note are the series by Soubrier et al., Delalande et al. and Mori et al. ${ }^{14-16}$.

Painful trigeminal sensory neuropathy has also been described in patients with type- 2 diabetes and appears to be closely associated with poor glycemic control ${ }^{12}$.

Because ITSN is an exclusion diagnosis, the patient must be investigated carefully. MRI testing is essential for this purpose, as it allows the origin, ganglion and the whole path of the fifth cranial nerve to be visualized accurately. In some cases of ITSN, gadolinium enhancement of the cisternal segment has been detected ${ }^{17}$, causing confusion with trigeminal neurinoma during diagnosis, with neurosurgery sometimes being recommended ${ }^{18-20}$.

Table. Causes of sensory dysfunction in the trigeminal nerve region.

\begin{tabular}{|c|c|c|}
\hline \multicolumn{3}{|l|}{ Intracranial } \\
\hline Congenital & Syringobulbia & \\
\hline \multirow[t]{14}{*}{ Acquired } & Inflammatory & Multiple sclerosis \\
\hline & & $\begin{array}{l}\text { Neurosyphilis, tuberculosis, Hansen's disease, HIVIAIDS, herpes virus, Epstein-Barr virus, viral } \\
\text { hepatitis }\end{array}$ \\
\hline & & Diabetes mellitus \\
\hline & & Acute sinusitis \\
\hline & & Sarcoidosis \\
\hline & & $\begin{array}{l}\text { Connective tissue diseases (Sjogren's disease, systemic sclerosis, mixed connective tissue disease, } \\
\text { rheumatoid arthritis, systemic lupus erythematosus) }\end{array}$ \\
\hline & & Advanced kidney disease \\
\hline & & Lupus anticoagulant syndrome \\
\hline & Neoplastic & Brain tumors \\
\hline & Vascular & Cerebrovascular diseases \\
\hline & Drugs & $\begin{array}{l}\text { Acetazolamide, ergotamines, hydralazine, isoniazide, labetalol, methysergide, monoaminoox- } \\
\text { idase inhibitors, nalidixic acid, nitrofurantoin, phenytoin, propranolol, ritonavir, streptomycin, } \\
\text { sulphonylureas, sulthiame, tricyclic antidepressants, mefloquine, alpha interferon. }\end{array}$ \\
\hline & Occupational & Vinca alkaloids \\
\hline & Idiopathic & Benign trigeminal sensory neuropathy \\
\hline & & Anxiety disorders \\
\hline
\end{tabular}

Extracranial

$\begin{array}{ll}\text { Trauma } & \text { Infraorbital, inferior alveolar, lingual, mental, middle cranial fossa fracture } \\ \text { Inflammatory } & \text { Osteomyelitis } \\ \text { Neoplastic } & \text { Carcinoma of nasopharynx } \\ & \text { Metastatic tumors }\end{array}$




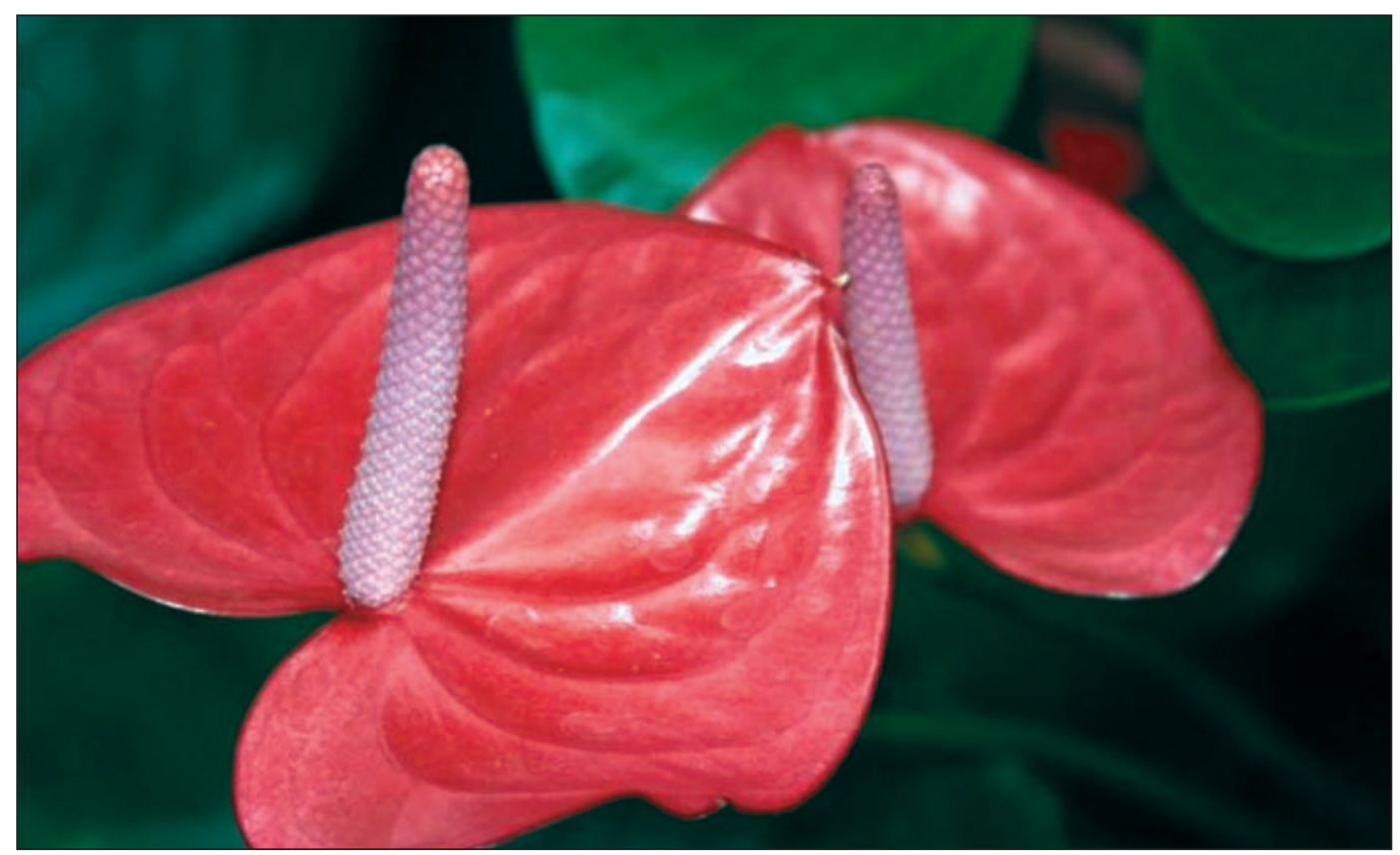

Fig 1. Anthurium flower (Anthurium sp.)

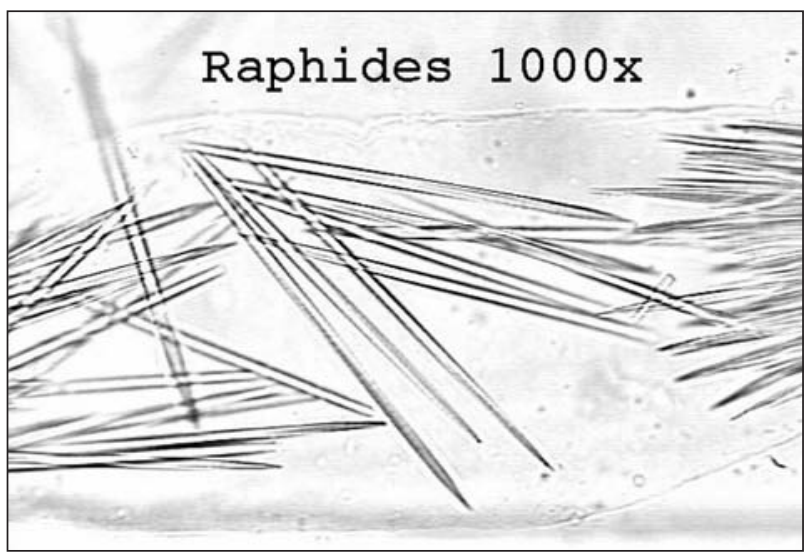

Fig 2. Calcium oxalate raphide crystals (Anthurium sp).

The TSN case reported here occurred after the patient had experienced localized facial dermatitis as the result of exposure to the ornamental plant anthurium. The patient's clinical condition improved remarkably, with only symptomatic medication (carbamazepine) being used to control pain and paresthesia.

The anthurium flower (Anthurium sp.) comes from Colombia and belongs to the family Araceae. It can be easily grown and is found mainly in hot, humid regions. It is one of the most sought after tropical plants and one of the most widely used for ornamental purposes (Fig 1) ${ }^{21,22}$. When ingested, it can cause irritation of the oral mucosa and the throat. It contains calcium oxalate raphide crystals (Fig 2), which are the main irritant and can easily penetrate the mucosae to produce symptoms shortly after any part of the plant is ingested or merely chewed. Manifestations such as mucosal irritation; edema (swelling) of the lips, tongue and palate; a painful burning sensation; drooling; difficulty in swallowing; abdominal colic; nausea; and vomiting then appear ${ }^{21-23}$.

The role of the crystals produced by these plants is to regulate calcium levels and provide protection against herbivores ${ }^{23}$. As well as irritant crystals, these plants produce toxic proteins that have not yet been fully identified ${ }^{23}$. Interestingly, calcium oxalate has already been implicated in other cranial neuropathies, such as those caused by ethylene glycol poisoning and chronic renal insufficiency ${ }^{24,25}$.

Finally, we would like to draw attention to this rare case, which is, to our knowledge, the first report of the association between trigeminal sensory neuropathy and contact dermatitis due to Anthurium sp.

\section{REFERENCES}

1. Dumas M, Perusse R. Trigeminal sensory neuropathy: a study of 35 cases. Oral Surg Oral Med Oral Pathol Oral Radiol Endod 1999;87:577-582.

2. Penarrocha M, Alfaro A, Bagan JV, Lopez-Trigo J. Idiopathic trigeminal sensory neuropathy. J Oral Maxillofac Surg 1992;50:472-476.

3. Lecky BR, Hughes RA, Murray NM. Trigeminal sensory neuropathy: a study of 22 cases. Brain 1987;110:1463-1485.

4. Robinson CM, Addy L, Wylie M, Luker J, Eveson JW, Prime SS. A study of the clinical characteristics of benign trigeminal sensory neuropathy. J Oral Maxillofac Surg 2003;61:325-332.

5. Penarrocha-Diago M, Mora-Escribano E, Bagan JV, Penarrocha-Diago M. Neoplastic trigeminal neuropathy: presentation of 7 cases. Med Oral Patol Oral Cir Bucal 2006;11:E106-111.

6. Kim JS, Lee MC, Kim HG, Suh DC. Isolated trigeminal sensory change due to pontine hemorrhage. Clin Neurol Neurosurg 1994;96:168-169.

7. Stranjalis G, Sakas DE. Post-traumatic transient bilateral trigeminal neuropathy. Acta Neurochir (Wien) 2002;144:307-308. 
8. Chang WK, Mulford GJ. Iatrogenic trigeminal sensorimotor neuropathy resulting from local anesthesia: a case report. Arch Phys Med Rehabil 2000;81:1591-1593

9. Watt-Smith S, Mehta K, Scully C. Mefloquine-induced trigeminal sensory neuropathy. Oral Surg Oral Med Oral Pathol Oral Radiol Endod 2001;92:163-165.

10. Bandyopadhyay SK, Dutta A. Isolated trigeminal sensory neuropathy complicating end stage renal disease. J Assoc Physicians India 2005;53: 226-227.

11. Hagen NA, Stevens JC, Michet CJ Jr.Trigeminal sensory neuropathy associated with connective tissue diseases. Neurology 1990;40:891-896.

12. Takayama S, Osawa M, Takahashi Y, Iwamoto Y. Painful neuropathy with trigeminal nerve involvement in type 2 diabetes. J Intern Med Res 2006;34:115-118.

13. Marey-Lopez J, Sousa CP. Trigeminal sensory neuropathy related to interferon-alpha treatment. Muscle Nerve 2006;33:581-582.

14. Soubrier M, Vidailhet M, Clavelou P, et al. Trigeminal neuropathy and connective tissue diseases. Ann Med Interne (Paris) 1993;144:379-382.

15. Mori K, Iijima M, Koike H, et al. The wide spectrum of clinical manifestations in Sjogren's syndrome-associated neuropathy. Brain 2005;128: 2518-2534.

16. Delalande S, Seze J, Fauchais AL, et al. Neurologic manifestations in primary Sjogren syndrome : a study of 82 patients. Medicine (Baltimore) 2004;83:280-291.
17. Seidel E, Hansen C, Urban PP, Vogt T, Muller-Forell W, Hopf HC. Idiopathic trigeminal sensory neuropathy with gadolinium enhancement in the cisternal segment. Neurology 2000;54:1191-1192.

18. Rorick MB, Chandar K, Colombi BJ. Inflammatory trigeminal sensory neuropathy mimicking trigeminal neurinoma. Neurology 1996;46:145-147.

19. Dominguez J, Lobato RD, Madero S, Benito-Leon J, Rivas JJ, Gomez PA. Surgical findings in idiopathic trigeminal neuropathy mimicking a trigeminal neurinoma. Acta Neurochir (Wien) 1999;141:269-272.

20. Savas A, Deda H, Erden E, Kanpolat Y. Differential diagnosis of idiopathic inflammatory trigeminal sensory neuropathy from neuroma with a biopsy: case report. Neurosurgery 1999;45:1246-1249.

21. Lampe KF, McCann MA. AMA, Handbook of poisonous and injurious plants. Chicago: American Medical Assoc, 1985:432.

22. Fuller TC, McClintock E. Poisonous plants of California. Berkeley: Univ. California Press, 1986:432.

23. Franceschi VR, Nakata PA. Calcium oxalate in plants: formation and function. Ann Rev Plant Biol 2005;56:41-71.

24. Spillane L, Roberts JR, Meyer AE. Multiple cranial nerve deficits after ethylene glycol poisoning. Ann Emerg Med 1991;20:208-210.

25. Bilbao JM, Berry H, Marotta J, Ross RC. Peripheral neuropathy in oxalosis: a case report with electron microscopic observations. Can J Neurol Sci 1976;3:63-67. 